\title{
OCCUPATIONAL OVERUSE SYNDROME AND ITS SEVERITIES IN SOFTWARE PROFESSIONALS OF RUPANDEHI DISTRICT, NEPAL
}

\author{
Dr. Indra Dhakal ${ }^{1}$ Dr. Shanta Sharma ${ }^{2}$
}

\begin{abstract}
INTRODUCTION:

Prevalence of occupational overuse syndrome (OOS) is not new in computer professionals. Occupational overuse syndromes are diseases of the modern era and rank first among the health problems in the frequency with which they affect the quality of life. As the IT has been developed in a rapid way the different health problems are emerging in the same way which is of great concern. Some are caused by occupational exposures, and are marked with direct professional relation, or the action of harmful effects in the workplace.
\end{abstract}

\section{MATERIAL \& METHODS:}

A descriptive study was conducted in software professionals of Rupandehi district, Nepal. Data was collected as per pretested structured Performa from 270 respondents randomly and analyzed by using SPSS, MS-excel and Chi-square test to determine associations between categorical variables.

\section{RESULTS:}

The results of the study showed that majority of respondents belonged to 20-30 years of age, 74.4 per cent of respondents were male and 25.6 per cent were female, major occupational overuse syndrome was headache, back pain and neck pain. Majority of respondent's (56.3\%) working duration was 3-6 years and increased health problems are observed with increase in work duration.

\section{CONCLUSION:}

The present study concluded that majority of respondents had health problems and the major occupational overuse syndromes were headache, back pains, neck pain. Study also concludes that there is a relation between working duration and health problems, and the problems increase as the duration at work increases.

KEY WORDS: Occupational overuse syndromes, severity, software professionals

1. Consultant Orthopedic Surgeon, Department of Orthopedics, Lumbini Zonal Hospital, Butwal.

2. Lecturer, Department of Community Medicine, Devdaha Medical College and Research Institute, Rupandehi, Nepal.

\author{
For Correspondence \\ Dr. Indra Dhakal \\ Consultant Orthopedic Surgeon, \\ Lumbinal Zonal Hospital, Butwal \\ Email:drindradhakal@gmail.com
}




\section{INTRODUCTION:}

Occupational Overuse Syndrome (OOS) is the term given to a range of conditions characterized by discomfort or persistent pain in muscles, tendons and other soft tissues. These conditions are usually caused or aggravated by poor work processes and unsuitable working conditions that involve repetitive or forceful movements or the maintenance of constrained or awkward postures. OOS is also known as Repetitive Strain Injury (RSI).

In the twenty-first century, computers have become almost as ubiquitous as the humble pen and paper in many peoples' daily life. There are approximately six computers per thousand populations with an installation of 18 million personal computers (PCs) in the world and their number is increasing all the time. ${ }^{2}$ However, the long periods of working at a computer can cause musculoskeletal problems, eyestrain, and overuse injuries of the hands and wrists which can be reduced or eliminated with proper workstation design and improved posture. The proliferation of video display terminals (VDT), in the modern office setting has generated concern, related to potential health hazards associated with their use. Using the wrong chair or just sitting improperly in front of a computer for long time can lead to chronic debilities such as stiffness, headache, and backache ${ }^{3,4}$.

Revolution in information technology (IT) is happening worldwide with great pace. About $30 \%$ of the work force in developed and much more in the developing countries report with work related problems. Each year, $8 \%$ of working Dutch citizens takes time off from work due to RSI (Repetitive Strain Injuries) syndromes. According to Canadian report $10 \%$ of Canadian young adults report with $\mathrm{RSI}^{5}$.

A number of investigators have indicated that visual symptoms occur in $75-90 \%$ of computer operators ${ }^{6}$. About $76 \%$ of computer professionals in India reported musculoskeletal pain and discomfort in various epidemiological studies. Studies done in western countries and in India show a high prevalence of OOS in computer professionals and computer users. Of which, studies done in Serbia and Nigeria report the prevalence rate of musculoskeletal complaints to be $55.8 \%$ and $21 \%$ respectively. On the other hand studies done in India in Delhi, Mumbai, Loni Maharashtra, and four metropolitan cities report the prevalence rate to be $76.5 \%, 63 \%, 73.3 \%$ and $59 \%$ respectively. Furthermore subjects have reported a high incidence of musculoskeletal symptoms, particularly in neck, lower back, shoulder, upper back, wrist and hand ${ }^{7,8,49}$. Nepal has been making new developments in the IT sector. This is reflected in the emergence of call centers, software development companies, and the cyber cities. The number of computer users in Nepal is therefore on the rise and this is expected to increase further in the coming years. There is currently no data pertaining to OOS in Nepal. The main aim of this study is to evaluate the prevalence of Occupational Overuse Syndrome (OOS) among software professionals.

\section{MATERIAL \& METHODS:}

Objective: To identify Occupational Overuse Syndromes and Severity in Software Professionals of Rupandehi District Nepal.

Justification: A few decades ago, the development of automobile was made throughout the world, but now it is era of Information Technology that has already gripped the world in its fingers. By the increasing demand on IT and software professionals, the health problems are also emerging in a fast way and Nepal is not the exception. Many health related problems occurs in software professionals due to excessive exposure to computers, improper positioning of the body, repetitive strain on the eyes and also some psychological pressure but no sufficient studies have been conducted. So, it's very significant to study such things whose scope and demand is increasing day by day throughout the world but the research are very minimal. Occupational overuse syndrome can be easily prevented or reduced if proper precaution and guidelines are followed, so to reduce such problems this study is very crucial.

Methodology: This was a descriptive study conducted at Lumbini Zonal Hospital, Rupandehi from 1st February 2012 to $30^{\text {th }}$ of March, 2012. Rupandehi District is the $2^{\text {nd }}$ largest district with Software Professionals after Capital. There are 118 software Industries in Rupandehi district. Purposely 50 industries were selected. Two hundred seventy consecutive software professionals from Software Industry of Rupandehi District (Both male and female working for 3 or more years) were studied. Data was collected with the help of structured questionnaire as well as direct interview by the researcher. The collected data was entered, edited, categorized and coded in MS Office Excel Sheet. Analysis was done in SPSS 16 and Chi-square test was performed to establish association.

\section{RESULTS:}

Table I-shows that majority of respondents belonged to age group 20-30 years that is 60.7 per cent followed by age group 
$30-40$ years that is 28.1 per cent and very less were in $50-60$ age group that is 1.5 per cent.

\begin{tabular}{|l|c|c|}
\hline Age (yrs) & Frequency & Percent \\
\hline $20-30$ & 151 & 60.7 \\
\hline $30-40$ & 76 & 28.1 \\
\hline $40-50$ & 26 & 9.6 \\
\hline $50-60$ & 4 & 1.5 \\
\hline Total & 270 & 100.0 \\
\hline
\end{tabular}

Table I. Age wise distribution of the respondents

Table II-shows 74.4 per cent of respondents were male and 25.6 per cent were female. Majority of respondents were male.

\begin{tabular}{|l|c|c|}
\hline Sex & Frequency & Percent \\
\hline Female & 69 & 25.6 \\
\hline Male & 201 & 74.4 \\
\hline Total & 270 & 100.0 \\
\hline
\end{tabular}

\section{Table II. Sex wise distribution of the respondents}

Table III-shows that majority of respondent's work duration was 3-6 years that is 56.3 per cent followed by $7-10$ years that is 27.8 per cent and more 10 years duration was found in very few respondents that is 15.9 per cent.

\begin{tabular}{|l|l|l|}
\hline Duration in this service & Frequency & Percent \\
\hline 3-6yrs & 152 & 56.3 \\
\hline 7-10yrs & 75 & 27.8 \\
\hline more than 10yrs & 43 & 15.9 \\
\hline Total & 270 & 100.0 \\
\hline
\end{tabular}

\section{Table III. Working duration of the respondent}

Table IV-shows that majority of respondents work load was moderate that is 49.3 per cent in which 52.2 per cent were female and 48.3 per cent male, and then very less number of respondents had very low work load that is 3.7 per cent in which 4.3 per cent were female and 3.5 per cent were male.

\begin{tabular}{|l|c|c|l|}
\hline & \multicolumn{2}{|c|}{ Sex } & \\
\hline Work load & Female (\%) & Male (\%) & Total (\%) \\
\hline Very low & $3(4.3)$ & $7(3.5)$ & $10(3.7)$ \\
\hline Low & $11(15.9)$ & $53(26.4)$ & $64(23.7)$ \\
\hline IModerate & $36(52.2)$ & $97(48.3)$ & $133(49.3)$ \\
\hline High & $12(17.4)$ & $21(10.4)$ & $33(12.2)$ \\
\hline Very high & $7(10.1)$ & $23(11.4)$ & $30(11.1)$ \\
\hline Total & $69(100)$ & $201(100)$ & $270(100)$ \\
\hline
\end{tabular}

Table IV. Work load as reported by the respondents

Table V-shows that maximum number of respondents were having headache as a severe occupational overuse syndrome that is 11.5 per cent followed by low back pain that is 9.3 per cent and none of the respondents had severe knee pain.

\begin{tabular}{|l|l|l|l|c|c|}
\hline \multicolumn{1}{|c|}{ Syndromes } & absent & present & Mild & Moderate & Severe \\
\hline Low back pain & 36.7 & 63.3 & 36.7 & 17.4 & 9.3 \\
\hline Neck pain & 42.6 & 57.4 & 40 & 13 & 4.4 \\
\hline Shoulder pain & 61.9 & 38.1 & 28.1 & 8.9 & 1.1 \\
\hline Elbow pain & 74.4 & 25.6 & 20.7 & 4.4 & 0.4 \\
\hline Wrist pain & 70.7 & 29.3 & 23.3 & 5.2 & 0.7 \\
\hline Finger pain & 60.4 & 39.6 & 30.4 & 7.8 & 1.5 \\
\hline Headache & 36.7 & 63.3 & 33.7 & 18.1 & 11.5 \\
\hline Arm pain & 65.6 & 34.4 & 24.8 & 8.1 & 1.5 \\
\hline General body pain & 63.7 & 36.3 & 25.2 & 9.3 & 1.9 \\
\hline Hip pain & 77.8 & 22.2 & 18.1 & 3.7 & 0.4 \\
\hline Ankle pain & 82.2 & 17.8 & 13.7 & 2.6 & 1.5 \\
\hline Knee pain & 76.7 & 23.3 & 17.8 & 5.6 & 0 \\
\hline Foot pain & 73.3 & 26.7 & 21.1 & 4.4 & 1.1 \\
\hline Eye problem & 37.8 & 62.2 & 29.6 & 23.7 & 8.9 \\
\hline
\end{tabular}

Table V. Occupational Overuse Syndromes, Severities of Syndromes

Table VI-shows that majority of respondents working duration was 3-6 years that is 56.3 per cent with maximum respondents not having health problem that is 55.92 per cent and as the duration has increased health problems have also increased. 


\begin{tabular}{|l|l|l|l|}
\hline \multirow{2}{*}{ Duration } & \multicolumn{2}{|l|}{ Health problems } & \multirow{2}{*}{ Total (\%) } \\
\cline { 2 - 3 } & No (\%) & Yes (\%) & $152(56.3)$ \\
\hline $3-6$ year & $85(55.92)$ & $67(44.07)$ & $75(27.8)$ \\
\hline $7-10$ year & $25(33.33)$ & $50(66.66)$ & $43(15.9)$ \\
\hline 10 above & $15(34.88)$ & $28(65.11)$ & \\
\hline Total & $125(100)$ & $145(100)$ & $270(100)$ \\
\hline
\end{tabular}

\section{Table VI Effect of work duration on health problems}

\section{$\mathrm{X}^{2}=12.89$}

Level of significance $=0.05 \mathrm{df} 2=4.3$

Significant

\section{DISCUSSION:}

With rampant and excessive use of computers we are now entering into a new era of computer related health problems. Considering all these things a study was done in software Industry of Rupandehi district, Nepal with an objective, to identify different occupational overuse syndromes and severity in software professional of Rupandehi district, Nepal. In this study it was found that majority of respondents belonged to $20-30$ years of age (60.7 percent), this is the most productive age for work and most of them initiate their carrier at this age. Similar finding were shown in study by Shrilatha et al. $(2011)^{10}$. Majority of respondents were male and only one fourth were female. Majority of respondents work load was moderate (49.3 percent) and 56.3 percent of respondent were involved in software profession for 3-6 years, which is similar to study done by Kumari et al $(2010)^{11}$.

Present study shows that 145 respondents (53.7\%) are suffering from occupational overuse syndrome, among which eye problem $(62.2 \%)$, headache $(63.3 \%)$, back pain $(63.3 \%)$ and neck pain $(57.4 \%)$ were the major problem. Similarly a study done by Kumari et al. (2010) in India also shows that maximum number of respondents had back pain and eye pain as the major problems ${ }^{11}$. Several studies Talwar et al. (2009), Shrivastava SR et al. (2012), Sharma A et al. (2006) also shows similar results ${ }^{4,8,7}$.

Present study also shows that there is a significant relation between duration of respondent in a software profession and health problems. The prevalence of OOS increased as the duration increased, in 3-6 years duration $44.07 \%$ respondents had health problem, and in 7-10 years duration $66.66 \%$ respondents had health problems and in 10 years above 65.11 per cent respondents had health problems. Similar study was done by Subratty and Korumtoollee in 2005 found that Severity of pain increases with duration and number of hours of computer use at work ${ }^{12}$.

\section{CONCLUSION}

The present study concluded that majority $(60.7 \%)$ of the respondents belonged to 20-30 years of age which is the productive age. Majority (74.4\%) of the respondents were male and remaining respondents $(25.6 \%)$ were female. Study further concludes that majority of respondents were having occupational overuse syndrome, headache, back pain, neck pain and headache were commonest. Majority (49.3\%) of respondents' work load was moderate and then majority of respondent's $(56.3 \%)$ work duration was 3-6 years followed $27.8 \%$ respondents with work duration of 7 to 10 years and $15.9 \%$ respondents with work duration of more than 10 years. This study also concludes that there is a relation between duration of work and health problems, and the problems increases as the duration of work increases.

So, it is concluded that there are different health problems faced by software professionals which can be prevented and managed through proper installation of equipments as well as facilities and also through awareness related to such problems. Degree and pattern of computer use also should be modified and all other hazards and problems should be timely managed. 


\section{REFERENCES:}

1. Unionsafe. Factsheet: Occupational Overuse Syndrome.

2. Griffiths KL. A literature review on the impact of a computerized work environment on professional occupational group and behavioural and physiological risk factors for musculoskeletal symptoms. Journal of Occupation Rehabilitation. 2007; 17(4): 734-65. Available from: www.ncbi.nlm.nih.gov/pubmed/.com.

3. Singh S, Wadhwa J. Impact of computer workstation design on health of the users. Journal of Hum Ecol 2006 Nov; 20(3):16570 .

4. Talwar R, Kapoor R, Puri K, Bansal K, Singh S. A Study of Visual and Musculoskeletal Health Disorders among Computer Professionals in NCR Delhi. Indian Journal of Community Medicine.2009 Oct;34(4):326-8.

5. Bongers PM, Vet HC, Blatter BM. Repetitive strain injury (RSI): occurrence, etiology, therapy and prevention. Ned Tijdschr Geneeskd. 2002 Oct 19; 146(42):1971-6.

6. Zulima Palacio, Alison Graham. Study on visual symptoms among computer operators. Washington-DC,06,September, 2010.Available-from:-http://voanews.com/english/news/ american-life/.
7. Sharma A, Khera S, Khandekar J. Computer related health problems among information technology professionals in Delhi. Indian Journal of Community Medicine 2006;31(1):3-6.

8. Shrivastava SR, Bobhate PS. Computer related health problems among software professionals in Mumbai $\square$ : A cross-sectional study. 2012;1(2):74-8.

9. Vijay A.Work Related musculoskeletal health disorders among the information technology professionals in India. Int. J. Manag. Res. Bus. Strateg. 2013:2(2):118-28.

10. Srilatha G, Arun M, Bhat V, Sathiakumar N. Prevalence of workrelated wrist and hand Musculoskeletal Disorder amount computer users, Karnataka State, India. Journal of Clinical and Diagnostic Research 2011; 5(3): 605-607.

11. Kumari G, Pandey K, .Khanaka S. Studies on Health Problems of Software People: A Case Study of Faculty of GCE and GIMT Gurgaon, India. International Journal of Innovation, Management and Technology 2010; 1(4): 388-397.

12. Subratty $A H$ and Korumtoollee F. Occupational Overuse Syndrome among keyboard users in Mauritius. Indian journal of occupational and Environmental Medicine 2005; 9(2):71-75. 